\title{
EFFECT OF THE PROPORTION OF NATURAL GAS IN THE FEEDING DOSE ON THE COMBUSTION PROCESS IN A SELF-IGNITION ENGINE WITH A COMMON RAIL FUEL SYSTEM
}

\author{
Sławomir WIERZBICKI \\ University of Warmia and Mazury in Olsztyn, Faculty of Technical Sciences, \\ 11 Oczapowskiego St., 10-957 Olsztyn, Poland, e-mail: slawekw@uwm.edu.pl
}

Abstract

Limited oil resources, combined with the need to stem the toxic emissions to the atmosphere, necessitate seeking alternative fuels for combustion engines. According to forecasts, natural gas will be one of those fuels whose importance is likely to increase in future. Because of its properties, natural gas can be used directly in spark-ignition engines. When natural gas is used as fuel in much more efficient self-ignition engines, it is necessary to use dual fuelling.

This paper presents the effect of the proportion of natural gas in the feed dose on the course of the combustion process in a turbocharged self-ignition engine. The engine was controlled by the Common Rail fuel system, programmed for single-fuel operation.

Keywords: natural gas, self-ignition engine, combustion process, Common Rail system

\author{
WPŁYW UDZIAŁU GAZU ZIEMNEGO W DAWCE ZASILAJĄCEJ NA PRZEBIEG \\ SPALANIA W SILNIKU O ZAPŁONIE SAMOCZYNNYM Z UKŁADEM ZASILANIA \\ TYPU COMMON RAIL
}

Streszczenie

Ograniczone zasoby ropy naftowej, a także konieczność ograniczenia emisji związków toksycznych do atmosfery wymuszają poszukiwanie alternatywnych paliw do silników spalinowych. Według prognoz jednym z paliw którego znaczenie w przyszłości będzie wzrastać jest gaz ziemny. Ze względu na właściwości gaz ziemny może być bezpośrednio wykorzystywany do zasilania silników o zapłonie iskrowym. W przypadku wykorzystania gazu ziemnego do zasilania znacznie sprawniejszych silników o zapłonie samoczynnym konieczne jest zastosowanie dwupaliwowego układu zasilania.

$\mathrm{W}$ artykule przedstawiono wpływ udziału gazu ziemnego $\mathrm{w}$ dawce zasilającej na przebieg procesu spalania w turbodoładowanym silniku o zapłonie samoczynnym. W trakcie badań silnik był sterowany układem zasilania typu Common Rail oprogramowanym do pracy jednopaliwowej.

Keywords: gaz ziemny, silnik o zapłonie samoczynnym, przebieg procesu spalania, układ Common Rail.

\section{INTRODUCTION}

Limited oil resource, as well as efforts aimed at controlling the global warming, necessitate the search for new solutions in fuel systems, as well as alternative fuels which can help to limit toxic emissions. Natural gas will be one of those fuels whose importance is likely to increase in the nearest future. The properties of natural gas make it suitable as fuel for spark-ignition engines; however, studies are being conducted at various research centres on its use in fuel self-ignition engines. Due to the relatively high self-ignition temperature of methane, which is the main component of natural gas $(823 \mathrm{~K})$, it can be used in self-ignition engines only with dual fuel systems. In this case, for the gas fuel in the engine cylinder to ignite, it is necessary to inject a small amount of liquid fuel, whose self- ignition initiates the combustion of gas fuel $[4,5$, $10,15]$.

Studies of the dual fuel system indicate that this method of fuelling an engine helps to increase its overall efficiency. It is particularly noticeable for high engine loads. Moreover, with such a fuelling system of self-ignition engines, the NOx emission and the smoke content in exhaust gas is reduced noticeably $[1,2,6,8,11,16]$.

Most authors point out some negative effects of this type of fuel, namely, an increase in THC and CO emission [2, 9, 12, 17].

The presence of gas fuel supplied with air significantly changes the parameters of the fuel mixture in the cylinder. Due to the larger volume occupied by gas compared to liquid fuel, the volume of air drawn into the cylinder is reduced, which decreases the concentration of air in the 
combustion chamber. Moreover, with large portions of gas fuels in the feed dose, a gas-air mixture forms in the combustion chamber, which significantly changes the rate of flame propagation in the cylinder [15].

As indicated by the findings of experiments [1, $2,9,10,11,15,18]$, as well as simulation studies $[5,6,7,8]$, the presence of methane in an engine cylinder alters the course of the combustion process. First of all, when gas fuel is supplied to the engine with air, the temperature of the working medium in the engine cylinder decreases. This is associated with the presence of methane in the cylinder, which has much higher specific heat than air. It extends the liquid self-ignition delay and, in consequence, results in greater pressure increase during the initial phase of combustion.

Most studies of the use of natural gas to fuel self-ignition engines have been conducted on small one-cylinder engines or on older generation ones. There have been relatively few studies describing the course of combustion of gas fuels in selfignition engines with the Common Rail fuel system, which is the current standard in engines of this type.

Considering the principle of operation of the Common Rail system, the presence of gas fuel in the engine cylinder is likely to alter the course of combustion considerably. In engines with the CR fuel system, a small dose of liquid fuel, called a pilot dose, is usually injected very early. When liquid fuel is supplied, its purpose is to raise the temperature in the engine cylinder in order to improve the conditions of combustion of the main fuel dose by shortening the self-ignition delay. Therefore, it must be assumed that with a dual fuel system, an injection of the pilot dose of liquid fuel with a high proportion of natural gas in the fuel dose can cause ignition of gas fuel. In consequence, it results in uncontrolled fuel combustion, which can decrease the engine efficiency.

The aim of the experiments described below was to determine the effect of the proportion of natural gas in the fuel dose on the course of the combustion process in the self-ignition turbo engine with the CR fuel system programmed for singlefuel operation.

\section{TEST STAND}

The experiment was conducted on a fourcylinder turbocharged ADCR engine fitted out with a Common Rail 2.0 system made by Bosch. The main parameters of an engine operation are characterised in Table 1.

The engine under study was mounted at the AVL experimental stand, which ensures controlled engine load and measurement of the basic operation parameters, including: rotation speed, torque, fuel consumption and concentration of toxic compounds in exhaust gas. A view of an engine mounted at the experimental stand is shown in Fig. 1.
To analyse the effect of the proportion of natural gas in the feed dose on the course of the combustion process, a Kistler 6056A pressure gauge was placed in one cylinder in the glow plug. A signal from the sensor is conducted through the Kistler 5018A charge amplifier to a computer via a DAQ card, which enabled registration of pressure changes in the engine cylinder vs. rotation speed of the crankshaft. The momentary position of the crankshaft was determined with an optical sensor with a resolution of $0.5^{\circ} \mathrm{CA}$.

Table 2. Technical data of the ADCR engine

\begin{tabular}{|l|l|}
\hline Engine & ADCR \\
\hline Engine type & $\begin{array}{l}\text { Diesel, 4-cycle, turbocharged with } \\
\text { charge air cooler }\end{array}$ \\
\hline $\begin{array}{l}\text { Number and arrangement } \\
\text { of cylinders }\end{array}$ & 4 cylinders in-line, vertical \\
\hline $\begin{array}{l}\text { Bore diameter / piston } \\
\text { stroke }\end{array}$ & $94 / 95 \mathrm{~mm}$ \\
\hline Swept volume & $2636 \mathrm{~cm}^{3}$ \\
\hline Compression ratio & $17,5: 1$ \\
\hline Rated power* / speed & $85 \mathrm{~kW} / 3700 \mathrm{rpm}$ \\
\hline Peak torque*/speed & $250 \mathrm{Nm} / 1800-2200 \mathrm{rpm}$ \\
\hline $\begin{array}{l}\text { Specific fuel consumption } \\
\text { at peak torque* }\end{array}$ & $210 \mathrm{~g} / \mathrm{kWh}$ \\
\hline Injection system & Common Rail CR2.0 (Bosch) \\
\hline Turbocharger & $\begin{array}{l}\text { radial, with exhaust extraction } \\
\text { valve }\end{array}$ \\
\hline
\end{tabular}

* in accordance with ISO 1585

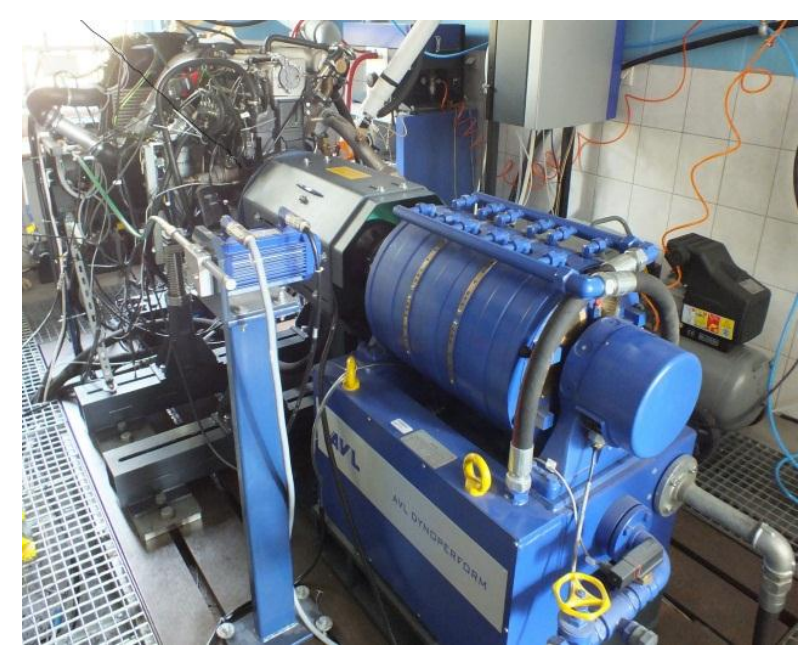

Fig. 1. Test bench

To determine the effect of the proportion of natural gas in the fuel dose on the course of the combustion process, an installation was developed feeding gas fuel to the engine. During the construction of the gas installation, particular attention was paid to ensure a constant dose of gas fuel fed to the engine [15]. A precisely defined dose of gas fuel was fed to the suction manifold before the turbocharger. Owing to such a method of feeding the gas fuel, a uniform gas-air mixture could be formed in the engine cylinders. Compressed natural gas containing $97.8 \%$ of methane was used as gas fuel during the study. The calorific value of the gas fuel was $36.374 \mathrm{MJ} / \mathrm{m} 3$. The diagram of the installation is shown in Fig. 2. 
During the experiment, the engine was controlled by the EDC16C39 controller manufactured by Bosch. The controller had original software to control the engine, adapted for singlefuel operation. Depending on the actual conditions of the engine operation, such as the rotation speed or the load, the controller implements various control strategies. During the experiment, the engine control system maintained a constant engine load by adjusting the fuel dose depending on the engine work conditions and the dose of the gas fuel. With an increasing proportion of the gas fuel, it reduced the dose of liquid fuel injected to the combustion chamber.

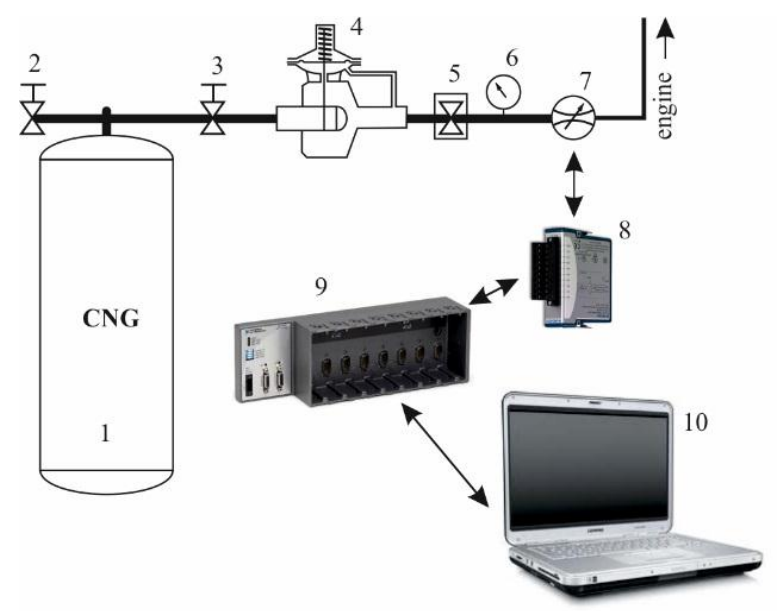

Fig. 2. Block diagram of the gaseous fuel supply system: 1 - CNG tank, 2 - filling valve, 3 - cutoff valve, 4 - two-stage reducer, 5 - solenoid valve, 6 - pressure gauge, 7 - MasStream gas mass flow regulator, 8 - i/o card to control the flow regulator, 9 - CompactRio programmable controller, 10 - computer PC

The energy proportion of the gas fuel $\left(U_{g}\right)$ in the engine feed dose at this stage of the experiment was determined from the following formula:

$$
\mathrm{U}_{\mathrm{g}}=\frac{\dot{\mathrm{m}}_{\mathrm{CNG}} \cdot \mathrm{W}_{\mathrm{CNG}}}{\dot{\mathrm{m}}_{\mathrm{on}} \cdot \mathrm{W}_{\mathrm{on}}} \cdot 100 \%
$$

where:

$\dot{m}_{\text {on }}$ - stream of fuel oil during single-oil operation $[\mathrm{kg} / \mathrm{min}]$;

$\dot{m}_{C N G}$ - stream of CNG fed to the engine $[\mathrm{Nl} / \mathrm{min}]^{1}$; $W_{\text {on }}-$ calorific value of fuel oil $[\mathrm{kJ} / \mathrm{kg}]$;

$W_{C N G}-$ calorific value of $\mathrm{CNG}[\mathrm{kJ} / \mathrm{Nl}]$.

\section{METHODOLOGY OF DETERMINING THE COMBUSTION PROCESS PARAMETERS}

The analysis of the course of the combustion process was based on the pressure trajectory averaged from 50 successive cycles of pressure in the engine cylinder. The average pressure trajectory

\footnotetext{
${ }^{1} \mathrm{Nl}$ - normal litre (normal $\mathrm{m}^{3}$ ), i.e. gas volume calculated for the "normal state", i.e. at the pressure of 1.013 bar and temperature of $0^{\circ} \mathrm{C}$;
}

was subsequently smoothed out with the "SavitzkyGolay filter method" procedure.

Numerical procedures, as well as functions available in the Matlab computational environment, were used for further calculations [8].

The smoothed-out pressure trajectory was used to calculate the heat release trajectory based on the first law of thermodynamics and the equation of state for the enclosed part of cycle from $\alpha_{1}=220$ ${ }^{\circ} \mathrm{OWK}$ (enclosing the inlet valve to $\alpha_{2}=490$ (opening the outlet valve). Assuming that a change in the system energy caused by a fuel injection is negligibly small and that the medium in the cylinder can be modelled as ideal gas, the heat evolution trajectory $d Q_{n} / d \alpha$ was calculated as:

$$
\frac{d Q_{n}}{d \alpha}=\frac{\gamma}{\gamma-1} p \frac{d V}{d \alpha}+\frac{1}{\gamma-1} V \frac{d p}{d \alpha}
$$

Calculations were conducted using the constant specific heat index adopted after Heywood [3] $\left(\gamma=c_{p} / c_{v}=1.36\right)$.

The $d Q_{n} / d \alpha$ values calculated in this manner were subsequently adjusted for the heat exchanged with the cylinder walls, the head surface and the piston bottom, with the resulting trajectory $d Q / d \alpha$ describing the course of the combustion process, where:

$$
\frac{\mathrm{dQ}}{\mathrm{d} \alpha}=\frac{\mathrm{dQ}_{\mathrm{n}}}{\mathrm{d} \alpha}-\frac{\mathrm{dQ}_{\mathrm{s}}}{\mathrm{d} \alpha}
$$

where:

$d Q_{s} / d \alpha$ - stream of heat exchanged with the cylinder walls, piston and head bottom.

The mechanism of heat exchange was limited to the convection between the medium and the cylinder walls:

$$
\frac{\mathrm{dQ}_{\mathrm{s}}}{\mathrm{d} \alpha}=\mathrm{H}_{\mathrm{c}}(\alpha) \cdot \mathrm{A}_{\mathrm{s}}(\alpha) \cdot\left(\mathrm{T}(\alpha)-\mathrm{T}_{\mathrm{s}}\right)
$$

A constant average wall temperature of $T_{s}=120^{\circ} \mathrm{C}$ was adopted. The wall area $A_{s}(\alpha)$ depending on the crankshaft rotation angle, was calculated from the kinematic relationships of the crank system. The temperature of the charge in the cylinder for each $\mathrm{CR}$ angle $T(\alpha)$ was calculated based on the state equation with the number of moles determined from air and gas consumption at a specific operation point. The heat exchange index $H_{c}(\alpha)$ was calculated in accordance with the Hohenberg model [3]

The total heat released during the combustion process was calculated by integration of the heat evolution trajectory $d Q / d \alpha$ over the full calculation interval from $\alpha_{1}$ to $\alpha_{2}$.

\section{RESULTS}

The engine controller implemented two liquid fuel strategies. The fuel dose was divided into two doses at lower speeds regardless of the load; ca. 20$30^{\circ}$ before the TDC the pilot dose was injected. The 
beginning of the main dose injection started several degrees before TDC. Only one fuel dose was injected at higher rotation speeds and medium and great loads and its injection started several degrees before TDC. Two fuel doses were injected at a small load.

During the experiment, the assumed dose of the gas fuel was fed into the engine inlet manifold, and the engine controller selected the liquid fuel dose while maintaining the assumed engine load.

Fig. 3 and Fig. 4 show the time series of pressure in the cylinder and of heat evolution at $\mathrm{n}=1500 \mathrm{rpm}$, for various proportions of gas fuel in the fuel dose $\left(U_{g}\right)$ at various engine loads referred to the time series with single-fuel feed. In order to make the interpretation of results easier, the start of the pilot dose and of the main dose of the fuel oil was marked in the pressure graph. It is seen clearly in Fig. 3 and Fig. 4 of the graphs that the presence of gas fuel in the feeding dose slightly reduces the pressure during the compression, which reduces the temperature in the cylinder during the compression stroke. This results in a delay in liquid fuel selfignition and, after the combustion process is initiated, more rapid increase in pressure and heat evolution. It should be linked with initiation of gas fuel combustion as a result of self-ignition of the pilot dose of fuel oil. Fig. 3 shows clearly that the pressure increase and heat evolution trajectory increase with the proportion of gas fuel in the feed dose.

Fig. 5 and Fig. 6 show similar trajectories as in Fig. 3 and Fig. 4, recorded at 3,000 rpm for two different loads. The trajectories presented here show clearly that an increase in the gas fuel proportion in the feed dose considerably reduces the compression pressure and, in consequence, the temperature in the cylinder. This results in a considerable increase in the self-ignition delay.

In effect, the heat evolution rate increases, which is a consequence of a higher proportion of the liquid fuel dose upon self-ignition and, at the same time, relatively rich gas-air mixture. The intensity of heat evolution increases with the proportion of gas fuel in the feed dose.

When a proportion of gas fuel in the feed dose is high and at higher rotation speeds, when a relatively small dose of fuel oil is required, the control system starts injecting the pilot dose. Injection of this dose significantly alters the course of combustion in the combustion chamber. Early injection of this fuel dose significantly accelerates heat evolution, which increases the load on the piston-crank system and increased heat loss.

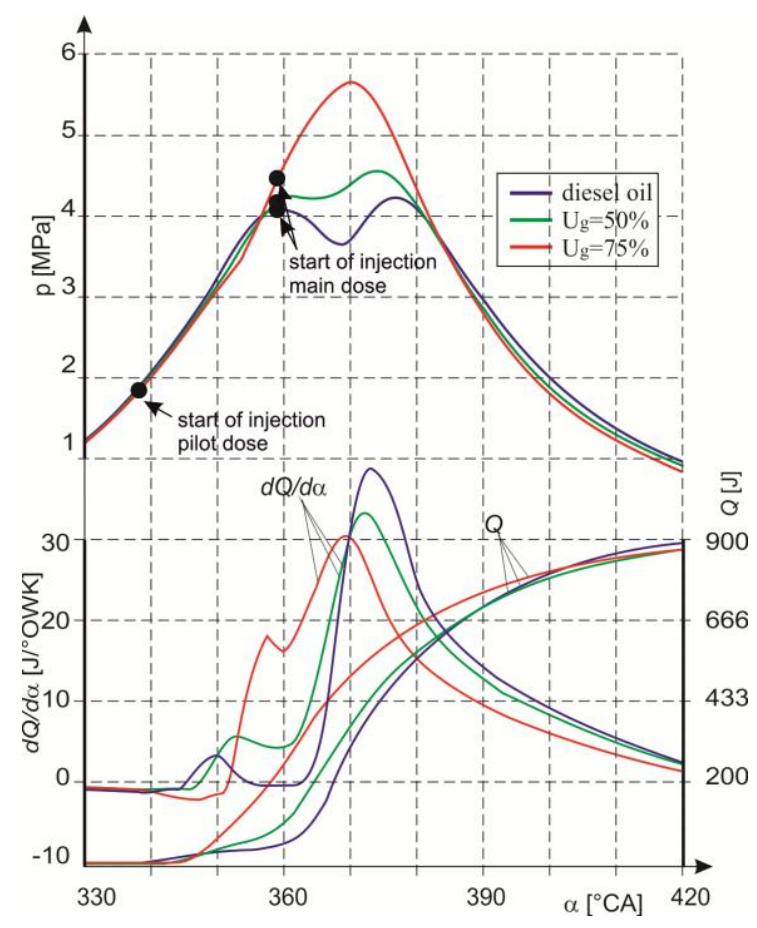

Fig. 3. The pressure and heat evolution trajectory for the engine cylinder at $n=1500 \mathrm{rpm}, \mathrm{T}=100$ $\mathrm{N} \cdot \mathrm{m}$ for various proportions of gas fuel in the feed dose

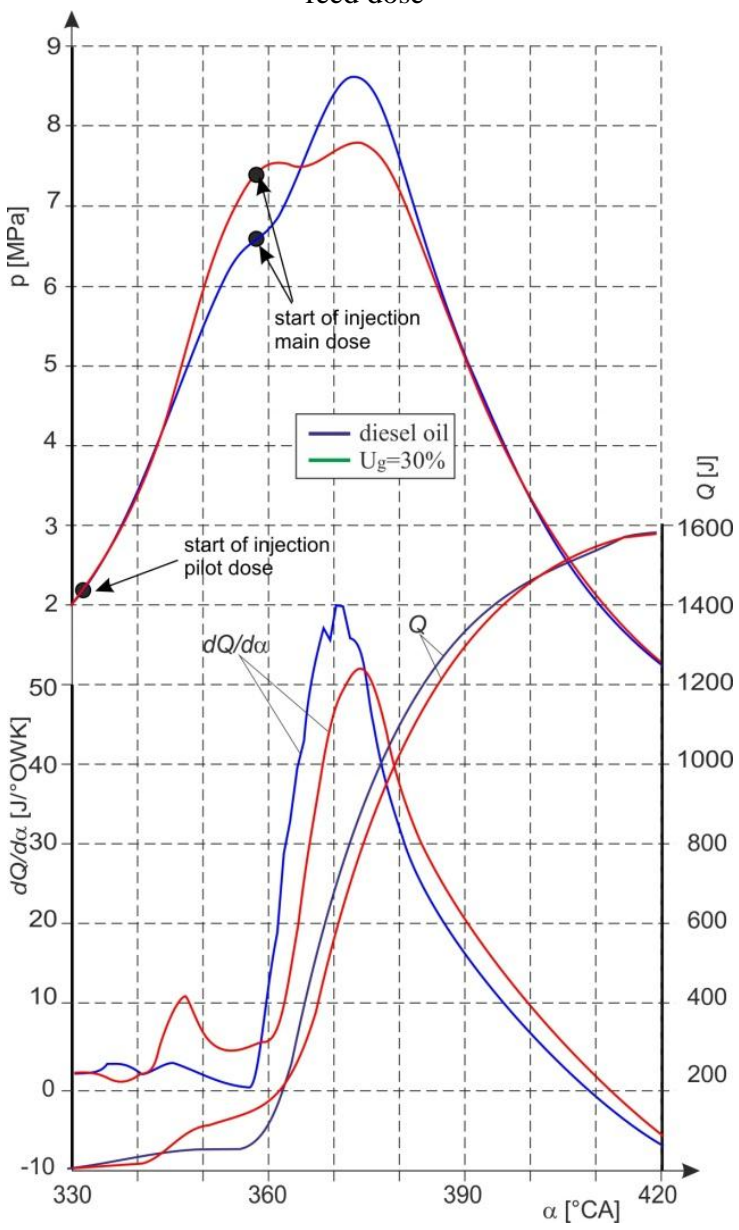

Fig. 4. The pressure and heat evolution trajectory for the engine cylinder at $n=1500 \mathrm{rpm}, \mathrm{T}=200$ $\mathrm{N} \cdot \mathrm{m}$ for various proportions of gas fuel in the feed dose 


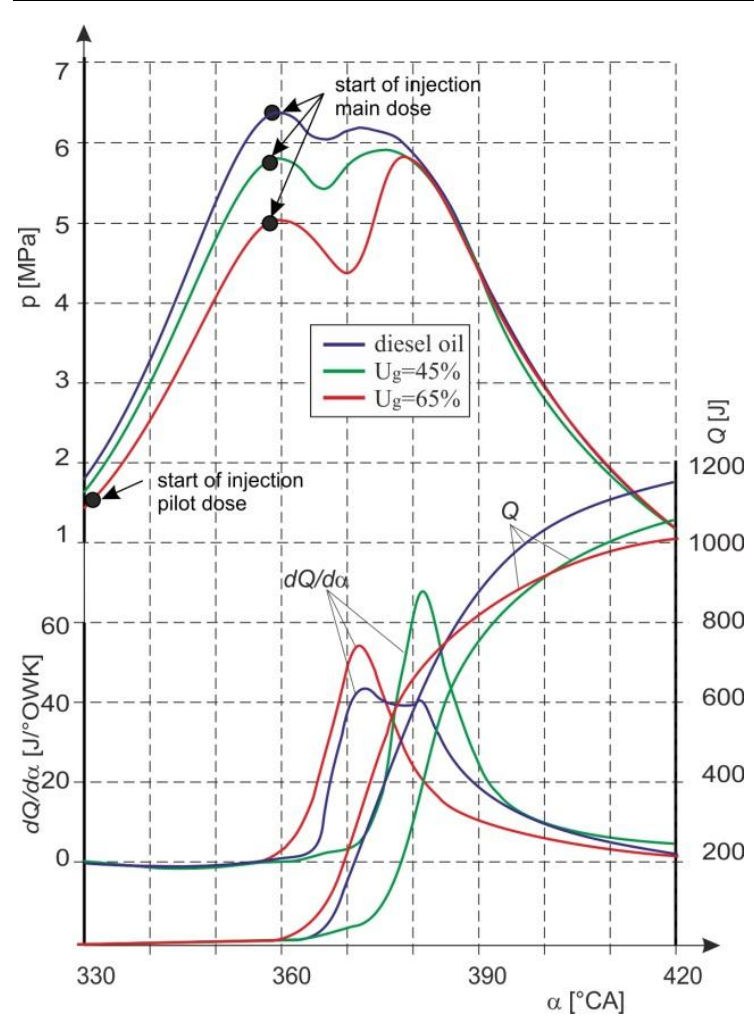

Fig. 5. The pressure and heat evolution trajectory for the engine cylinder at $n=3000 \mathrm{rpm}, \mathrm{T}=100$ $\mathrm{N} \cdot \mathrm{m}$ for various proportions of gas fuel in the feed dose

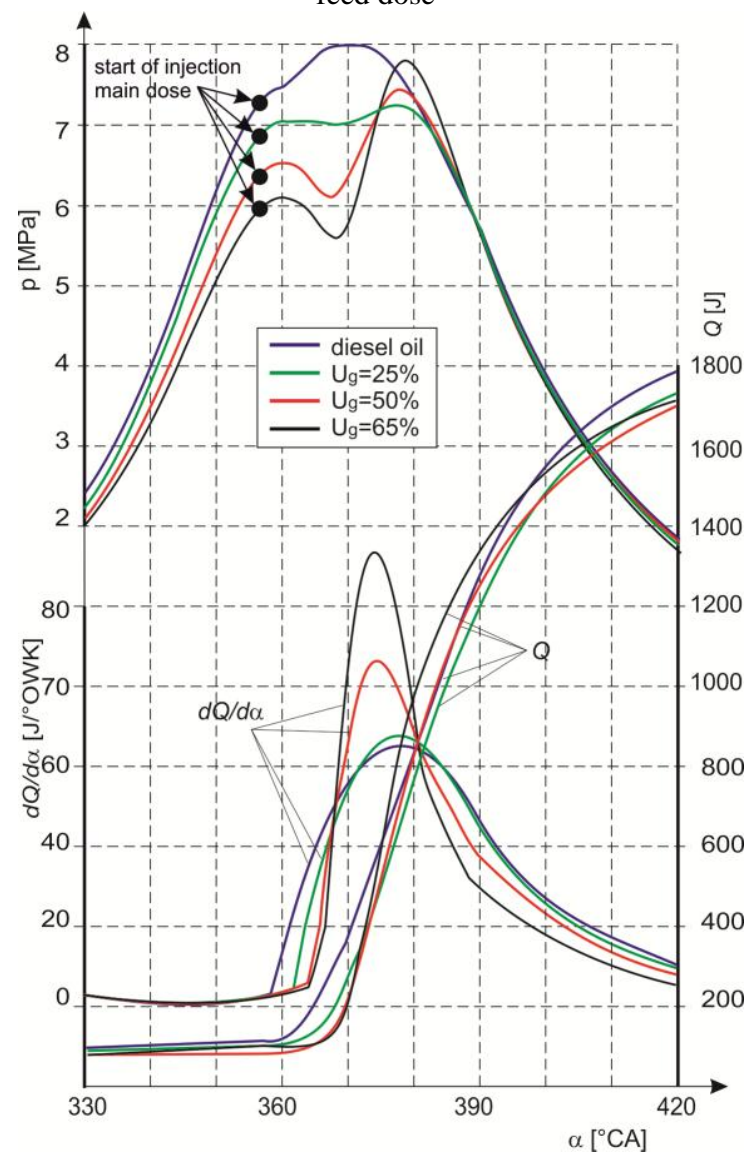

Fig. 6. The pressure and heat evolution trajectory for the engine cylinder at $\mathrm{n}=3000 \mathrm{rpm}, \mathrm{T}=200$ $\mathrm{N} \cdot \mathrm{m}$ for various proportions of gas fuel in the feed dose

\section{CONCLUSIONS}

This study has shown clearly that the proportion of natural gas in the feed dose in a self-ignition engine with the Common Rail fuel system significantly alters the course of combustion.

With a divided dose and early injection of the pilot dose, injection of this dose initiates combustion of gas fuel. It causes greater pressure increases at the initial phase of combustion and early heat evolution. In such a case, the intensity of heat evolution in the cylinder depends on the chemical composition of the gas-air mixture in the cylinder. With enriching the mixture, the intensity of heat evolution increases, which causes considerable heat loss.

At higher rotation speeds, when a single dose of liquid fuel is injected, its self-ignition is considerably delayed.

It should also be emphasised that feeding a dose of gas fuel is not detected by the engine operation supervision system complying with EOBD, despite a considerable change in the combustion process.

The effective use of natural gas to feed selfignition engines with Common Rail fuel systems requires a change of the engine control strategy, mainly a change of the injection advance angle. However, it must be emphasised that with a dualfuel engine feed it is not possible to properly control the course of combustion by grading the liquid fuel injection. The presence of gas fuel in the combustion chamber makes the combustion process start to run in a way dependent on the gas-air mixture properties.

In order to ensure full control of the course of combustion with dual-fuel feed of self-ignition engines, a system of direct fuel injection to the combustion chamber is required.

\section{REFERENCES}

1. Al-Saadi AAA, Aris IB. CNG-diesel dual fuel engine: A review on emissions and alternative fuels. Control Conference (ASCC), IEEE 2015. http://dx.doi.org/10.1109/ASCC.2015.7244858.

2. Liu J, Yang F, Wang H, Ouyang M, Hao S. Effects of pilot fuel quantity on the emissions characteristics of a $\mathrm{CNG}$ /diesel dual fuel engine with optimized pilot injection timing. Applied Energy. 2013;110:201-206. http://dx.doi.org/10.1016/j.apenergy.2013.03.024.

3. Heywood JB. Internal Combustion Engines Fundamentals. McGraw-Hill International. 1988.

4. Mikulski M, Wierzbicki S, Śmieja M, Matijošius J. Effect of CNG in a fuel dose on compression-ignition engine's combustion process. Transport. 2015; 30(2): 162-171.

http://dx.doi.org/10.3846/16484142.2015.1045938.

5. Mikulski M, Wierzbicki S, Piętak A. Numerical studies on controlling gaseous fuel combustion by managing the combustion process of diesel pilot dose in a dual-fuel engine. Chemical and Process Engineering - Inzynieria Chemiczna i Procesowa. 2015; 36(2): 225-238. http://dx.doi.org/10.1515/cpe2015-0015. 
6. Mikulski M, Wierzbicki S, Piętak A. Zerodimensional 2-phase combustion model in a dual-fuel compression ignition engine fed with gaseous fuel and a divided diesel fuel charge. Eksploatacja i Niezawodność - Maintenance and Reliability. 2015:17(1):42-48.

http://dx.doi.org/10.17531/ein.2015.1.6.

7. Mikulski M, Wierzbicki S. Numerical investigation of the impact of gas composition on the combustion process in a dual-fuel compression-ignition engine. Journal of Natural Gas Science and Engineering. 2016; 31: 525-537.

http://dx.doi.org/10.1016/j.jngse.2016.03.074.

8. Mikulski M, Wierzbicki S. Validation of a zerodimensional and 2-phase combustion model for dualfuel compression ignition engine simulation. Thermal Science. 2017;21(1B):387-399. http://dx.doi.org/10.2298/TSCI160127076M.

9. Ryu K. Effects of pilot injection pressure on the combustion and emissions characteristics in a diesel engine using biodiesel-CNG dual fuel. Energy Conversion and Management. 2013;76:506-516. http://dx.doi.org/10.1016/j.enconman.2013.07.085.

10. Stelmasiak Z, Larisch J, Pietras D. Selected problems of adaptation car diesel engine for dual fuel supplying. Combustion Engines 2015;(3): 1021-1029.

11. Tutak W, Jamrozik A, Pyrc M, Sobiepański M. A comparative study of co-combustion process of diesel-ethanol and biodiesel-ethanol blends in the direct injection diesel engine. Applied Thermal Engineering. 2017; 117:155-163. https://doi.org/10.1016/j.applthermaleng.2017.02.029

12. Tutak W, Jamrozik A, Bereczky Á, Lukacs K. Effects of injection timing of diesel fuel on performance and emission of dual fuel diesel engine powered by diesel/E85 fuels. Transport. 2018;33(3):633-646. https://doi.org/10.3846/transport.2018.1572.

13. Wang Z, Zhao Z, Wang D, Tan M, Han Y, Liu Z, Dou H. Impact of pilot diesel ignition mode on combustion and emissions characteristics of a diesel/natural gas dual fuel heavy-duty engine. Fuel. 2016;167:248-256.

http://dx.doi.org/10.1016/j.fuel.2015.11.077.

14. Wierzbicki S, Śmieja M, Grzeszczyk R. Zintegrowane sterowanie stanowiskiem badawczym silników o ZS w środowisku fast prototyping. Combustion Engines. 2013; 3(154): 536-541. Polish.

15. Wierzbicki S. Studium możliwości wykorzystania biogazu do zasilania silników o zapłonie samoczynnym. UWM Olsztyn, 2016. Polish.

16. Xu M, Cheng W, Li Z, Zhang H, An T, Meng Z. Preinjection strategy for pilot diesel compression ignition natural gas engine. Applied Energy. 2016. 179:1185-1193.

http://dx.doi.org/10.1016/j.apenergy.2016.07.024.

17. Yang B, Wang L, Ning L, Zeng K. Effects of pilot injection timing on the combustion noise and particle emissions of a diesel/natural gas dual-fuel engine at low load. Applied Thermal Engineering. 2016;102: 822-828.

http://dx.doi.org/10.1016/j.applthermaleng.2016.03.1 $\underline{26}$.
18. Yang B, Wei X, Xi C, Liu Y, Zeng K, Lai MC. Experimental study of the effects of natural gas injection timing on the combustion performance and emissions of a turbocharged common rail dual-fuel engine. Energy Conversion and Management. 2014; 87:297-304.

http://dx.doi.org/10.1016/j.enconman.2014.07.030.

\section{Received 2017-12-22}

Accepted 2018-11-02

Available online 2018-11-05

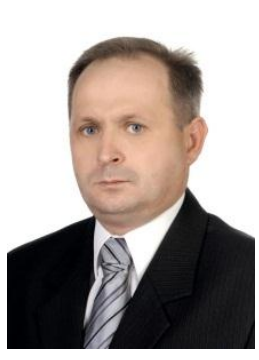

\section{Ph.D., D.Sc. Sławomir}

WIERZBICKI - professor at the Department of Mechatronics. He is also Deputy Dean of the Faculty of Technical Sciences of the UWM in Olsztyn and Head of the Department of Mechatronics.

In his work, he deals with fuelling modern self-ignition combustion engines and electronic systems which supervise the operation and diagnostics of vehicles and machinery.

$\mathrm{He}$ is a member of the Polish Technical Diagnostics Association, Polish Scientific Combustion Engines Association and the Polish Scientific and Technical Maintenance Association. 